\title{
KEJADIAN CEDERA PADA KARYAWAN INDUSTRI PERCETAKAN DI KOTA MAKASSAR
}

\section{OCCURANCE OF INJURY OF WORKER IN THE PRINTING INDUSTRY IN MAKASSAR CITY}

\author{
A. Muflihah Darwis ${ }^{1}$, M. Furqaan Naiem ${ }^{1}$, Ade Wira Lisrianti Latief ${ }^{2}$, Rizky Maharja ${ }^{2}$, \\ Noviponiharwani ${ }^{3}$, Muhammad Rum Rahim ${ }^{1}$, Magfirah Ramadhani ${ }^{1}$ \\ ${ }^{1}$ Bagian Kesehatan dan Keselamatan Kerja, Fakultas Kesehatan Masyarakat \\ Universitas Hasanuddin, Makassar \\ ${ }^{2}$ Bagian Hiperkes dan Keselamatan Kerja, Akademi Hiperkes Makassar \\ ${ }^{3}$ Bagian Sanitasi, Poltekkes Muhammadiyah, Makassar \\ Email Korespondensi: amuflihah@ unhas.ac.id
}

\begin{abstract}
ABSTRAK
Pertumbuhan jumlah industri percetakan dibarengi dengan makin tingginya angka kejadian cedera akibat kecelakaan kerja. Meningkatnya jumlah kecelakaan kerja menyebabkan kecelakaan kerja menjadi masalah serius karena kebutuhan kegiatan pencetakan akan meningkat. Tujuan dari penelitian ini untuk mengetahui pola terjadinya cedera akibat kecelakaan kerja pada pekerja di industri percetakan di Makassar. Sampel berjumlah 146 responden dengan kriteria hanya karyawan yang bertindak sebagai operator percetakan. Hasil penelitian menunjukkan bahwa cedera dialami oleh 106 karyawan $(72,6 \%)$ dengan menghasilkan 269 kejadian $(92,8 \%)$ cedera. Jenis cedera tertinggi yaitu luka teriris sebanyak 34,9\%. Bagian tubuh yang menjadi letak cedera tertinggi yaitu pada jari tangan sebanyak $61,5 \%$. Alat pemotong merupakan penyebab cedera tertinggi dari kategori peralatan sebanyak 27,7\%, Thinner merupakan penyebab cedera tertinggi dari kategori bahan sebanyak $12,4 \%$, dan Lantai merupakan penyebab cedera tertinggi dari kategori bangunan sebanyak $15,7 \%$. Ceroboh merupakan penyebab cedera tertinggi dari aspek perilaku karyawan yaitu sebanyak $52,8 \%$.
\end{abstract}

Kata kunci: Cedera, Kecelakaan Kerja, Industri Percetakan

\begin{abstract}
Growth the number of the printing industry is also accompanied by the high incidence of injuries caused work accidents. The increasing number of occurance injury caused work accident become serious problem because requirement of printing activity will be increasing. To determine the pattern occurance of injury caused work accident of worker in the printing industry in Makassar. The sample of 146 respondents with the criteria only employees who act as printing operator. The results showed that injuries were experienced by 106 employees (72,6\%) resulting in 269 events $(92,8 \%)$ injuries. The highest type of injury is $34.9 \%$ cuts. The part of the body where the highest injury is in the finger is $61,5 \%$. Cutting tools are the highest cause of injury in the equipment category as much as 27,7\%, Thinner is the highest cause of injury in the material category as much as 12,4\%, and the floor is the highest cause of injury in the building category as much as 15,7\%. Careless is the highest cause of injury from the aspect of employee behavior that is as much as $52,8 \%$.
\end{abstract}

Key Word: Injury, Work Accident, Printing Industry 


\section{PENDAHULUAN}

Industrialisasi merupakan suatu keharusan di kebanyakan negara di dunia karena menjamin kelangsungan proses pembangunan ekonomi yang tinggi. Meski demikian, perlu juga diakui bahwa industrialisasi itu sendiri bukan merupakan tujuan akhir, melainkan hanya merupakan salah satu strategi yang harus ditempuh untuk mendukung proses pembangunan.

Pertumbuhan jumlah industri sektor kecil merupakan konsekuensi dari pertambahan penduduk, termasuk jenis industri percetakan. Setiap negara memiliki setidaknya 60 pabrik percetakan, lebih dari 1000 karyawan dan lebih dari 190 juta Dolar produksi. Negara rata-rata memiliki pabrik percetakan lebih dari 700 dengan 20.000 karyawan. Di Amerika Serikat, terdapat 36.870 industri percetakan dengan mempekerjakan lebih dari 1 juta pekerja (Davis, 2009).

Menurut data kementrian perindustrian, jumlah perusahaan industri percetakan di Indonesia sebanyak 27.209 percetakan. Kota Makassar, data dari Dinas Perindustrian dan Perdagangan Kota Makassar, pada tahun 2009 terdapat 30 percetakan yang terdaftar dengan mempekerjakan sebanyak 111 pekerja, tahun 2010 terdapat 22 percetakan dengan tenaga kerja sebanyak 82 pekerja, dan tahun 2011 terdapat 25 percetakan dengan mempekerjakan sebanyak 112 pekerja (Disperindag, 2012).

Pertumbuhan jumlah industri percetakan juga dibarengi dengan makin tingginya angka kejadian cedera akibat kecelakaan kerja. Di United Kingdom, terdapat lebih dari 560 kecelakaan dilaporkan dalam Reporting of Injuries, Diseases and Dangerous Occurrences Regulations (RIDDOR) pada tahun 2009-2010 untuk industri percetakan, yang terdiri dari penanganan manual sebanyak 27\%, penanganan lain 4\%, kontak dengan mesin yang bergerak 22\%, terpeleset $22 \%$, kejatuhan benda $8 \%$, jatuh dari ketinggian 7\%, dan jenis kecelakaan lain 10\% (HSE, 2011).

Data kecelakaan kerja nasional di Indonesia yang diperoleh dari Departemen Tenaga Kerja dan Transmigrasi (Depnakertrans) Republik Indonesia, pada tahun 2006 terjadi 95.624 kasus, tahun 2007 terjadi 83.714 kasus, dan tahun 2008 terjadi 73.195 kasus yang terdiri dari $4.32 \%$ mengalami cacat fungsi, 2,82\% cacat sebagian, dan $0,03 \%$ mengalami cacat total (Mayendra, 2009).

Seringnya terjadi cedera akibat kecelakaan kerja di industri percetakan merupakan masalah yang serius mengingat kebutuhan akan kegiatan percetakan akan terus meningkat. Mengidentifikasi pola kejadian cedera akibat kecelakaan kerja merupakan bagian dari kegiatan investigasi kecelakaan kerja. Menurut Tarwaka (2008), investigasi kecelakaan kerja merupakan suatu kegiatan inspeksi tempat kerja secara khusus, yang dilakukan setelah terjadinya peristiwa kecelakaan kerja yang menimbulkan penderitaan kepada manusia serta mengakibatkan kerugian bagi perusahaan.

Dengan demikian, kejadian cedera akibat kecelakaan kerja dan cedera yang timbul pada 
industri percetakan merupakan suatu hal yang sangat penting dilakukan untuk mendapatkan kesimpulan yang berguna bagi penyusunan program upaya pencegahan terjadinya kecelakaan akibat kerja di industri percetakan. Oleh karena itu, peneliti ingin melakukan penelitian mengenai pola kejadian cedera akibat kecelakaan kerja pada karyawan industri percetakan di Kota Makassar.

\section{BAHAN DAN METODE}

\section{Jenis Penelitian}

Jenis penelitian ini adalah penelitian kuantitatif deskriptif yang bertujuan memperoleh pola kejadian cedera pada pekerja industri percetakan di Kota Makassar.

\section{Lokasi dan Waktu Penelitian}

Penelitian ini dilaksanakan di Industri Percetakan di Kota Makassar yang terdaftar dalam Dinas Perindustrian dan Perdagangan Kota Makassar. Adapun waktu penelitian ini dilakukan pada bulan April 2013.

\section{Populasi dan Sampel}

Populasi dalam penelitian ini sebanyak 305 orang. Sampel sebanyak 146 sampel dari 68 percetakan, Metode penarikan sampel adalah Purposive Sampling. Metode pengambilan sampel sesuai dengan kriteria yang ditentukan oleh peneliti. yaitu sampel merupakan operator yang mengerjakan proses pencetakan.

\section{Teknik Pengumpulan Data}

Pengumpulan data diperoleh melalui metode wawancara dengan menggunakan kuesioner yang telah disiapkan. Dan data sekunder diperoleh dari
Dinas Perindustrian dan Perdagangan Kota Makassar.

\section{Penyajian Data}

Data diolah melalui sistem komputerisasi dengan menggunakan program SPSS dengan cara tabulasi data sesuai dengan pengelompokan variabel yang diteliti. Data tersebut kemudian disajikan dalam bentuk table, grafik, dan narasi.

\section{HASIL}

Berdasarkan hasil pengolahan data yang dilakukan, maka distribusi data yang diperoleh adalah sebagai berikut.

\section{Karakteristik Responden}

Karakteristik responden adalah ciri khas yang melekat pada diri responden. Dalam penelitian ini, karakteristik responden meliputi kelompok umur, jenis kelamin, dan pendidikan terakhir.

Berdasarkan umur menunjukkan bahwa dari 146 responden, persentase responden terbesar terdapat pada kelompok umur 20-24 tahun, yaitu sebanyak 40 orang $(27.4 \%)$ (Tabel 1).

Berdasarkan jenis kelamin menunjukkan bahwa menunjukkan bahwa mayoritas jumlah responden berjenis kelamin laki-laki yaitu sebanyak 114 orang $(78,1 \%)$ (Tabel 2).

Berdasarkan pendidikan terakhir menunjukkan bahwa menunjukkan menunjukkan bahwa jenis pendidikan yang paling tinggi adalah SMA yaitu sebanyak 88 orang (60.3\%) (Tabel 3). 
Muflihah, 2020

Tabel 1. Distribusi Responden Menurut

Kelompok Umur

\begin{tabular}{ccc}
\hline $\begin{array}{c}\text { Kelompok } \\
\text { Umur (Tahun) }\end{array}$ & $\mathbf{N}$ & $\boldsymbol{\%}$ \\
\hline $16-19$ & 15 & 10.3 \\
$20-24$ & 40 & 27.4 \\
$25-29$ & 28 & 19.2 \\
$30-34$ & 29 & 19.9 \\
$35-39$ & 17 & 11.6 \\
$40-44$ & 9 & 6.2 \\
$45-49$ & 6 & 4.1 \\
$\geq 50$ & 2 & 1.4 \\
\hline Total & 146 & 100 \\
\hline
\end{tabular}

Tabel 2. Distribusi Responden Menurut Jenis

Kelamin

\begin{tabular}{crc}
\hline Jenis Kelamin & n & \% \\
\hline Laki-laki & 114 & 78.1 \\
Wanita & 32 & 21.9 \\
\hline Total & 146 & 100 \\
\hline
\end{tabular}

Tabel 3. Distribusi Responden Menurut Jenis

Pendidikan

\begin{tabular}{lrc}
\hline Jenis Pendidikan & N & \% \\
\hline Tidak Sekolah & 3 & 2.1 \\
SD & 3 & 2.1 \\
SMP & 18 & 12.3 \\
SLTA: & & \\
1. SMA & 88 & 60.3 \\
2. SMK & 7 & 4.8 \\
3. STM & 2 & 1.4 \\
4. STM & 1 & 0.7 \\
GRAFIKA & 3 & 2.1 \\
D3 & 21 & 14.4 \\
S1 & 146 & 100 \\
\hline \multicolumn{1}{c}{$\quad$ Total } &
\end{tabular}

\section{Kejadian Cedera}

Hasil penelitian menunjukkan bahwa cedera dialami oleh 106 karyawan (72,6\%) dengan menghasilkan 269 kejadian $(92,8 \%)$ cedera (Tabel 4 \& 5). Jenis cedera tertinggi yaitu luka teriris sebanyak 34,9\% (Grafik 1). Bagian tubuh yang menjadi letak cedera tertinggi yaitu pada jari tangan sebanyak 61,5\% (Tabel 6). Alat pemotong merupakan penyebab cedera tertinggi dari kategori peralatan sebanyak $27,7 \%$, Thinner merupakan penyebab cedera tertinggi dari kategori bahan sebanyak $12,4 \%$, dan Lantai merupakan penyebab cedera tertinggi dari kategori bangunan sebanyak 15,7\% (Tabel 7). Ceroboh merupakan penyebab cedera tertinggi dari aspek perilaku karyawan yaitu sebanyak $52,8 \%$ (Grafik 2).

Tabel 4. Distribusi Responden Menurut Kejadian Kecelakaan Kerja

\begin{tabular}{lcc}
\hline $\begin{array}{c}\text { Kejadian } \\
\text { Kecelakaan }\end{array}$ & n & \% \\
\hline Pernah & 106 & 72.6 \\
Tidak Pernah & 40 & 27.4 \\
\hline Total & 46 & 100 \\
\hline
\end{tabular}

Tabel 5. Distribusi Kejadian Kecelakaan menurut Kejadian Cedera

\begin{tabular}{lrr}
\hline $\begin{array}{l}\text { Kejadian } \\
\text { Cedera }\end{array}$ & \multicolumn{1}{l}{ f } & \% \\
\hline Ya & 269 & 92.8 \\
Tidak & 21 & 7.2 \\
\hline Total & 290 & 100 \\
\hline
\end{tabular}


Grafik 1. Distribusi Kejadian Cedera Menurut Jenis Cedera

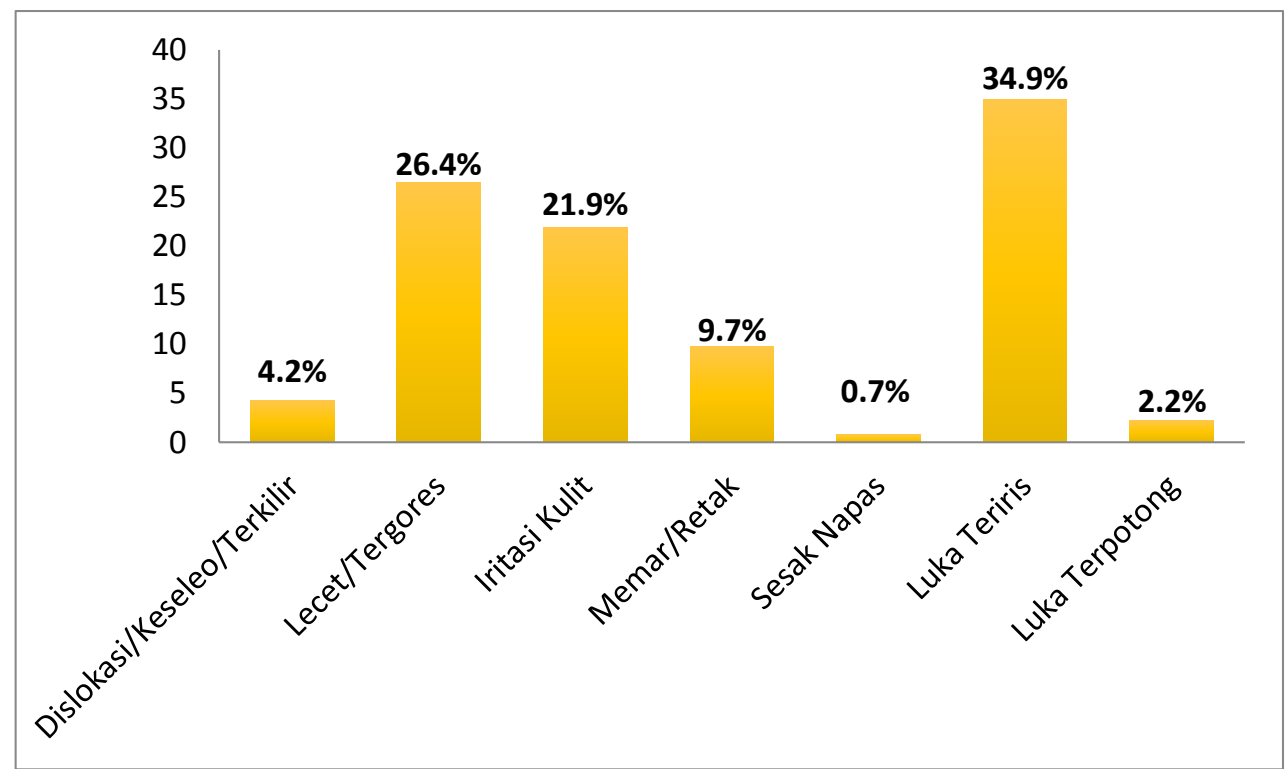

Tabel 6. Distribusi Kejadian Cedera Menurut Letak Cedera

\begin{tabular}{ccc}
\hline Letak cedera & f & \% \\
\hline Pundak & 6 & 2.1 \\
Lengan & 14 & 5 \\
Tangan & 45 & 16.2 \\
Jari Tangan & 171 & 61.5 \\
Kaki & 11 & 4 \\
Betis & 4 & 1.4 \\
Tumit & 1 & 0.4 \\
Mata & 9 & 3.2 \\
Hidung & 1 & 0.4 \\
Dada & 1 & 0.4 \\
Perut & 2 & 0.7 \\
Lutut & 8 & 2.9 \\
Jari Kaki & 5 & 1.8 \\
\hline Total & 278 & 100
\end{tabular}


Tabel 7. Distribusi Kejadian Cedera Menurut Penyebab Kecelakaan Kerja (Lingkungan Kerja )

\begin{tabular}{|c|c|c|}
\hline Penyebab Kecelakaan & $\mathbf{f}$ & $\%$ \\
\hline Peralatan & 225 & 52.8 \\
\hline Mesin Cetak & 30 & 7.0 \\
\hline Mesin Sablon & 23 & 5.4 \\
\hline Alat Pemotong & 118 & 27.7 \\
\hline Stapler & 3 & 0.7 \\
\hline Paku Tindis & 2 & 0.5 \\
\hline Gurinda & 11 & 2.6 \\
\hline Alat Pengebor & 1 & 0.2 \\
\hline Alat Pengelas & 4 & 0.9 \\
\hline Besi & 3 & 0.7 \\
\hline Palu & 22 & 5.2 \\
\hline Alat Pelubang & 2 & 0.5 \\
\hline Alat Press & 6 & 1.4 \\
\hline Bahan & 131 & 30.8 \\
\hline Tinta & 36 & 8.5 \\
\hline Tinner & 53 & 12.4 \\
\hline Lem & 9 & 2.1 \\
\hline Cat & 16 & 3.8 \\
\hline Kertas & 17 & 4 \\
\hline Material Bangunan & 70 & 16.4 \\
\hline Lantai & 67 & 15.7 \\
\hline Dinding & 3 & 0.7 \\
\hline Total & 426 & 100 \\
\hline
\end{tabular}

Grafik 2. Distribusi Kejadian Cedera Menurut Penyebab Kecelakaan Kerja (Perilaku)

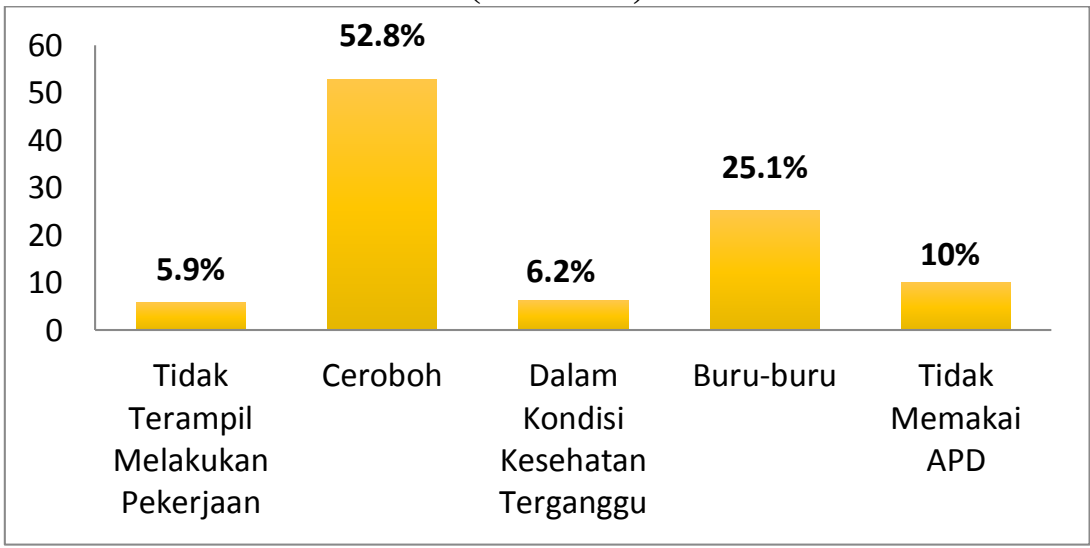




\section{PEMBAHASAN}

Kecelakaan kerja adalah kejadian yang berhubungan dengan pekerjaan yang dapat menyebabkan cedera atau kesakitan (tergantung dari keparahannya), kejadian kematian atau kejadian yang dapat menyebabkan kematian. Pengertian ini juga digunakan untuk kejadian yang dapat menyebabkan kerusakan lingkungan atau yang berpotensi menyebabkan merusak lingkungan (OHSAS, 18001:2007).

Dari hasil penelitian menunjukkan bahwa dari 146 responden yang menjadi sampel dalam penelitian ini, maka didapatkan hasil yaitu terdapat 106 responden atau $72 \%$ yang pernah mengalami kecelakaan kerja, sedangkan yang tidak pernah mengalami kecelakaan kerja sebanyak 40 responden atau $37.4 \%$. Adapun total jumlah kejadian kecelakaan kerja yang terhitung setahun terakhir ini (April 2012 sampai April 2013) yaitu sebanyak 290 kejadian. Jumlah tersebut berada dalam kategori sangat tinggi untuk ukuran sebuah kota jika dibandingkan dengan angka kejadian di United Kingdom dimana terdapat lebih dari 560 kejadian kecelakaan dilaporkan dalam Reporting of Injuries, Diseases and Dangerous Occurrences Regulations (RIDDOR) pada tahun 2009-2010 untuk industri percetakan (HSE, 2011). Responden yang mengalami kecelakaan yang paling sering ini merupakan seorang wanita yang berusia 23 tahun yang mengaku sering mengalami kecelakaan kerja disebabkan karena kecerobohannya. Ceroboh dapat terjadi akibat tergesa-gesa, karena kurangnya pertimbangan, dan rasa ingin cepat selesai. Selain itu, ceroboh juga bisa dikarenakan karena kurang berkonsentrasi dalam melakukan satu hal, seringkali konsentrasi terbagi dua sehingga, pekerjaan satu tidak terselesaikan dengan baik, karena memikirkan pekerjaan lainnya.

Hasil penelitian ini juga menunjukkan bahwa dari 290 kejadian kecelakaan kerja, 269 kejadian atau $92.8 \%$ mengakibatkan cedera, sedangkan 21 kejadian atau $7.2 \%$ lainnya tidak mengakibatkan cedera. Persentase tersebut lebih tinggi dibandingkan penelitian oleh Agbenorku et al (2010) yang dilakukan pada karyawan percetakan di Ghana, ditemukan bahwa sebanyak $67 \%$ kecelakaan kerja yang mengakibatkan cedera.

Kejadian cedera karena teriris juga memiliki persentase yang tinggi disebabkan aktivitas memotong sangat sering dilakukan oleh karyawan, baik pada saat tahap pra cetak, maupun finishing. Pemakaian alat pelindung tangan sangat jarang dilakukan karena karyawan menganggap pemakaian tersebut hanya akan mengganggu kelancaran pekerjaannya dan mengganggu kenyamanan mereka. Hasil penelitian ini sejalan dengan hasil pelaporan oleh Printing Industry Advisory Committee (PIAC, 2005), pada tahun 2003-2004 mekanisme kecelakaan tertinggi yang dialami oleh karyawan percetakan yaitu penanganan manual sebanyak $33 \%$, tergelincir/tersandung sebanyak $24 \%$, dan kontak dengan mesin cetak sebanyak $17 \%$.

Hasil penelitian menunjukkan bahwa bagian tubuh yang menjadi letak cedera tertinggi yaitu pada jari tangan sebanyak 171 cedera atau $61.5 \%$, 
kemudian pada tangan sebanyak 45 cedera atau 16.2\%. sama halnya dengan penelitian yang dilakukan oleh Kasim (2004) pada industri di Kota Makassar menemukan anggota gerak bagian atas merupakan letak cedera terbanyak yaitu $35.2 \%$. Jumlah total letak cedera pada tubuh ini melebihi jumlah kejadian cedera disebabkan karena terdapat beberapa kejadian yang memiliki cedera lebih dari satu bagian tubuh untuk satu kali kejadian.

Sebagian besar operator percetakan dalam penelitian ini juga mengaku kadang-kadang merasakan iritasi kulit pada jari tangannya ketika telah melakukan pekerjaannya, khususnya jika telah melakukan pekerjaan yang membuat mereka harus terpapar dengan bahan kimia. Menurut Cahyono (2010), iritasi menyebabkan peradangan pada permukaan di tempat kontak. Iritasi kulit bisa menyebabkan reaksi seperti eksim atau dermatitis. Iritasi pada alat-alat pernapasan yang hebat dapat menyebabkan sesak napas, peradangan dan oedema (bengkak).

Salah satu penyebab besarnya angka kejadian cedera pada jari tangan yang dialami oleh para karyawan percetakan adalah kurangnya kesadaran akan pemakaian sarung tangan sebagai alat pelindung bagi mereka pada saat bekerja. Meskipun memiliki pengetahuan dan pengalaman yang cukup akan terjadinya cedera di bagian jari tangan yang disebabkan karena tidak memakai APD, hal itu juga tidak mempengaruhi mereka untuk sadar akan pentingnya penggunaan APD. Salah satu alasan yang dominan adalah terganggunya aktivitas mereka jika memakai
APD pada saat bekerja. Mereka menginginkan desain dan bahan APD yang nyaman dan tidak mengganggu pekerjaan mereka pada saat bekerja.

Alat pemotong yang menjadi peralatan paling banyak menyumbang angka kecelakaan kerja dan umumnya menghasilkan cedera merupakan salah satu alat yang digunakan dalam proses pencetakan yang memiliki risiko berbahaya bagi penggunanya karena dilengkapi dengan pisau yang sangat tajam sehingga memiliki kekuatan besar dalam proses memotong (Prmob, 2012). Frekuensi pemakaian alat pemotong ini memang sangat intens karena proses potong memotong merupakan aktivitas yang sering dilakukan pada proses pencetakan. Hasil penelitian ini bertentangan dengan hasil penelitian oleh Agbenorku (2010) yang dilakukan pada karyawan percetakan di Ghana, ditemukan bahwa sebanyak $48.5 \%$ kejadian kecelakaan disebabkan oleh mesin cetak.

Selain alat pemotong, tinner juga termasuk penyebab kecelakaan dari kategori bahan berbahaya. Hal ini sesuai dengan teori Scheder (1990), bahwa tinner ini membantu kerja mesin cetak. Tinner biasanya dipisahkan dari bahan pengikatnya dan mempengaruhi ketahanan, peresapan, pengilapan, pengeringan, dan pelekatan tinta. Dampak terhadap kulit yakni apabila bahan tersebut kontak berulang kali atau yang berkepanjangan dapat menyebabkan hilangnya lemak alami dari kulit, yang mengakibatkan radang kulit non alergi dan penyerapan melalui kulit. Kondisi penyimpanan dan penanganan bahan ini harus sesuai dengan 
yang direkomendasikan.

Jumlah keterlibatan alat dan bahan sebagai penyebab kejadian kecelakaan kerja melampaui jumlah total kejadian kcelakaan kerja maupun kejadian cedera disebabkan karena terdapat beberapa kejadian kecelakaan yang melibatkan alat dan bahan dalam waktu yang sama.

Responden yang mengalami kecelakaan yang paling sering ini merupakan seorang wanita yang berusia 23 tahun yang mengaku sering mengalami kecelakaan kerja disebabkan karena kecerobohannya. Ceroboh dapat terjadi akibat tergesa-gesa, karena kurangnya pertimbangan, dan rasa ingin cepat selesai. Selain itu, ceroboh juga bisa dikarenakan karena kurang berkonsentrasi dalam melakukan satu hal, seringkali konsentrasi terbagi dua sehingga, pekerjaan satu tidak terselesaikan dengan baik, karena memikirkan pekerjaan lainnya.

\section{KESIMPULAN DAN SARAN}

Berdasarkan hasil penelitian mengenai pola kejadian cedera akibat kecelakaan kerja pada karyawan percetakan di Kota Makassar, bahwa kecelakaan kerja dialami oleh 106 karyawan dengan jumlah sebanyak 290 kejadian. Terdapat 269 kejadian cedera akibat kecelakaan kerja dari 290 total kejadian kecelakaan kerja.

Jenis cedera tertinggi yaitu luka teriris sebanyak 34,9\%. Bagian tubuh yang menjadi letak cedera tertinggi yaitu pada jari tangan sebanyak $61,5 \%$. Alat pemotong merupakan penyebab cedera tertinggi dari kategori peralatan sebanyak $27,7 \%$, Thinner merupakan penyebab cedera tertinggi dari kategori bahan sebanyak $12,4 \%$, dan Lantai merupakan penyebab cedera tertinggi dari kategori bangunan sebanyak 15,7\%. Ceroboh merupakan penyebab cedera tertinggi dari aspek perilaku karyawan yaitu sebanyak $52,8 \%$.

\section{DAFTAR PUSTAKA}

Agbenorku et al. 2010. Traumatic injuries among printing press workers in Kumasi, Ghana. Dalam Medicine and Medical Sciences Vol. 1(9) tahun 2010: 426-432. International Research Journal: Ghana.

Cahyono. 2010. Keselamatan Kerja Bahan Kimia di Industri. Yogyakarta: Gadjah Mada University Press

Davis. 2009. Facts and Figures. Amerika Serikat: Printing Industries of America

Dinas Perindustrian dan Perdagangan (Disperindag) Kota Makassar. 2012. Data Perusahaan 2009-2011.

HSE. 2011. Health and safety statistics for the printing industry. (online) http://www.hse.gov.uk/printing/statisti cs.htm diakses pada tgl. 26 November 2012

Kasim. 2004. Pola Kejadian Cedera Akibat Kecelakaan Kerja pada Tenaga Kerja Unit Produksi di PT. Industri Kapal Indonesia (Persero) Makassar Tahun 2003. Skripsi. Makassar: FKM Unhas Palin, 2012. Faktor yang Berhubungan dengan Kejadian Kecelakaan Kerja pada Karyawan Percetakan Sektor Informal di Kelurahan Ballaparang Kecamatan Rappocini Kota Makassar Tahun 2012. Skripsi. Makassar: FKM Unhas

Mayendra, Oni. 2009. Analisis Penyebab Kecelakaan Kerja Berulang di PT. X. Skripsi. Jakarta: Departemen K3 FKM UI

OHSAS 18001:2007. Sistem Manajemen 
Keselamatan dan Kesehatan Kerja. Persyaratan.

PIAC. 2005. Annual Report: Printing and Publishing Industries Health and Safety Targets and Performance 1999/00 to 2003/04. HSE: United Kingdom.

Prmob. 2012. Guillotine Cutter Keselamatan

- Jangan memotong jari-jari Anda. (online)

http://id.prmob.net/kertas/pemotongkertas/perlu-721355.html diakses pada tgl. 17 Desember 2012.

Scheder. 1990. Perihal Cetak Mencetak. Jakarta: Penerbit Kanisius.

Tarwaka. 2008. Keselamatan dan Kesehatan Kerja, Manajemen dan Implementasi K3 di Tempat Kerja. Surakarta: Harapan Press. 